\section{Helping Students to Automatize Multiplication Facts: A Pilot Study}

\author{
Barbara Allen-Lyall
}

$\begin{array}{ll}\text { Received: } & 26 \text { November } 2017 \\ \text { Revised: } \quad \text { 03 January } 2018 \\ \text { Accepted: } \quad 26 \text { January } 2018 \\ \text { ISSN: } 1307-9298 \\ \text { Copyright @ IEJEE } \\ \text { www.iejee.com }\end{array}$

DOI: 10.26822/iejee.2018438128

\begin{abstract}
Attaining automaticity with multiplication facts during the elementary school years provides students with a strong foundation for understanding the interrelationship of rational numbers and strengthening mathematics computation throughout schooling. Automaticity also supports the development of number sense and ongoing mathematics learning due to expansion of students' mathematics self-concept. This study explores the efficacy and feasibility of an intervention approach to facts acquisition for Grade 3 students in the northeastern U.S. Students in seven classrooms across two diverse suburban community schools participated in a ten-week supplementary intervention program designed to improve motivation for facts memorization and increase facts automaticity. An assessment of facts acquisition and retention was administered to participants the following September upon entering Grade 4. Analysis shows significant growth in facts acquisition and retention across study groups when compared to $4^{\text {th }}$ grade students' facts retention in the study schools during September of the previous year.
\end{abstract}

Keywords: Elementary school students, mathematics, multiplication facts, automaticity

\section{Introduction}

Attaining automaticity with multiplication facts is both a desirable and commendable accomplishment for elementary school students. Unfortunately, this learning task requires considerable effort for most children (Burns, Ysseldyke, Nelson, \& Kanive, 2015; Mahler, 2011), even with assistance by teachers in classrooms and families beyond the school day. Although it is a challenging process for many children, and for some teachers and families in support of students, allocating time and utilizing effective methods for acquiring multiplication facts automaticity is well spent given that facts automaticity has a significant impact on flexible computation, mathematics self-concept, and understanding of more advanced mathematical concepts during the elementary school years and into secondary education (Codding, Burns, \& Lukito, 2011; Geary, 1994; National Research Council, 2005).

\section{The problem in a larger context}

Internalized facts allow for efficient mental computations that make easier multi-step problem solving or recognizing and making connections between mathematical concepts, such as multiplication and division, ratio comparison, fraction equivalencies, or exploration of object relationships in the world of geometry (Chapin \& Johnson, 2006; National Research Council, 2005). Extending beyond successful school mathematics performance, broader options for college study and employment opportunity become increasingly likely when one feels confident in one's mathematical thinking and is able to demonstrate solid achievement (Atweh \& Clarkson, 2001; Marsh \& Hau, 2004; Valero, 2004; Williams \& Williams, 2010). For myriad reasons, facts acquisition becomes an educational gatekeeper to true mathematical literacy. Consequently, helping children to be successful with this seemingly small element of early mathematics learning truly matters in a world rife with challenges requiring the mathematical communication of ideas between and within fields (D'Ambrosio \& D'Ambrosio, 1994; Thomas, 2001).

\section{Historical perspective}

The importance of knowing multiplication facts is not a new concept, having been important throughout history for anyone wishing to efficiently compute (Boyer, 1991). In ancient times, multiplication tables were carved into stone, pressed into clay, or written on papyrus. The Babylonians took the notion of simple multiplication facts further and created tables of cubic numbers from the roots of numbers 1-32. While dates are uncertain, ancient peoples in China, India, Babylon and Egypt recorded the facts of their mathematical lives at minimum four thousand years ago (Dehaene, 1997; Smith, 1958). Half again as many years ago, the Egyptians developed a written calendar that rivals the mathematical and astronomical accuracy of any we might construct today (Smith, 1958). Understanding mathematics by studying the underpinnings of computation garnered personal and political power. This reality has traveled thousands of years into the present and will likely matter well into the future, even in the presence of technology that necessarily requires human creation. We continue to hold fast the notion that it is important for children to automatize facts for recall, even if it is possible to review factors and products on a constructed table of some sort, whether physical or digital. We are able to consider such ideas using new knowledge of the brain and mathematics cognition (Qin, Cho, Chen, Rosenberg-Lee, Geary, \& Menon, 2014).

\section{Reducing cognitive load}

When one internalizes multiplication facts, less brainpower is required to perform tasks that require more complex or 
successive arithmetic manipulations (Geary, 1999; Geary, Saults, Liu, \& Hoard, 2000). Flexible thinking and conceptual leaps between mathematical concepts are possible when products are not computed using successive addition or determined by visual inspection of tables or charts (Royer, 2003). The relationship between factors and products becomes a point of departure into more challenging mathematics. Beginning every new mathematical step forward with a return to multiplication as repeated addition or reliance upon visual assistance may interrupt intuitive mathematical thinking (Goswami, 2008).

Fluid mental computations are thwarted by the needs of working memory necessarily allocated to ascertaining the product of two factors or, conversely, the factors of a particular product. Memorizing facts reduces cognitive load, allowing for working memory to better allocate resources when processing number relationships required by more complex mathematics (Goswami, 2008; LeFevre, DeStefano, Coleman \& Shanahan, 2005).

\section{What has been done to help?}

Many student texts and mathematics programs for elementary age learners rely on unwieldy methods for teaching facts, possibly due to a higher percentage of small problems offered as examples (Hamann \& Ashcraft, 1986; Siegler, 1988). There are also few examples of how or when to focus on facts acquisition, with texts relying more on conceptual development because it is also important and often easier. Nevertheless, a poor success rate going back fifty years or more illustrates a long-standing deficit in facts automaticity by school children due to memorization challenges (National Research Council, 2005).

Because there is little help given in published mathematics programs (National Mathematics Advisory Panel, 2008), teachers continue to rely on methods that they themselves experienced, successfully or unsuccessfully, as young learners. Interestingly, a major 454-page U.S. mathematics achievement report by the National Research Council (2005), written and edited by scores of top researchers in mathematics education, failed to provide more than one and one-half pages of information related to single-digit multiplication due to little available research on this topic.

There is no doubt that the task of memorizing individual facts is important for school-age children. Nearly every adult has had to personally grapple with this process over the course of his or her own school history. Yet, finding dedicated time and methods to assist learners and guide teacher practice on this count is difficult at best.

\section{Purpose of this study}

1) To understand whether a dedicated multiplication facts instruction intervention improves facts acquisition and retention.

2) To investigate the feasibility of a ten-week instructional intervention within an elementary classroom schedule.

\section{Research questions}

1) Among a sample of 4 th grade students who were taught by the same set of teachers in two consecutive years, where students tested in year two received a pedagogical treatment in year one and students tested in year one did not, what is the relationship between having the treatment and two outcome measures for facts acquisition and retention (number of correct attempted questions and number of correct out of all possible questions)?

2) What is the feasibility of including a 30-minute multiplication facts exploration and practice session during the constraints of a school week?

\section{Methods}

Research design

This school-based study employed a quasi-experimental approach utilizing comparison groups rather than control groups. Since it was possible that students receiving the treatment would benefit from the instructional treatment, all Grade 3 students across the two schools participated in the treatment so that none were programmatically disadvantaged. The results of facts acquisition assessments administered when the 3rd grade treatment group students became 4th graders were compared with assessments administered to all 4th graders in the same schools the previous year.

A two-part teacher, principal, researcher reflection process provided qualitative data in support of determining intervention feasibility. The aim of the qualitative element of this pilot study is to inform the design of a follow-up mixed methods study with a more substantial qualitative element.

\section{Research sites}

Two community public schools in suburban cities with diverse student populations were selected for this study. As shown in Table 1. the student majority identifies as Hispanic or other minority, and a majority of study sites students receive free or reduced lunch. Most students in the study schools walk to school each day.

Table 1. Study Sites - School Demographics

\begin{tabular}{|c|c|c|c|c|}
\hline & Ethnic & $\begin{array}{l}\text { Socio- } \\
\text { economic }\end{array}$ & Gender & $\begin{array}{c}\text { School } \\
\text { Math } \\
\text { Scores }\end{array}$ \\
\hline \multirow{4}{*}{$\begin{array}{c}\text { School } \\
\# 1\end{array}$} & $\begin{array}{c}\text { Hispanic } \\
62.1 \%\end{array}$ & $\begin{array}{c}\text { Free Lunch } \\
60.3 \%\end{array}$ & $\begin{array}{c}\text { Female } \\
49 \%\end{array}$ & $\begin{array}{l}\text { Pass } \\
42.3 \%\end{array}$ \\
\hline & White $16.6 \%$ & $\begin{array}{c}\text { Reduced } \\
\text { Lunch } 12.6 \%\end{array}$ & Male $51 \%$ & \\
\hline & Black $17.0 \%$ & & & \\
\hline & Asian 3.8\% & & & \\
\hline \multirow{4}{*}{$\begin{array}{l}\text { School } \\
\# 2\end{array}$} & $\begin{array}{c}\text { Hispanic } \\
88.5 \%\end{array}$ & $\begin{array}{c}\text { Free Lunch } \\
72.5 \%\end{array}$ & $\begin{array}{c}\text { Female } \\
47 \%\end{array}$ & $\begin{array}{c}\text { Pass } \\
40.0 \%\end{array}$ \\
\hline & White $7.7 \%$ & $\begin{array}{c}\text { Reduced } \\
\text { Lunch } 14.6 \%\end{array}$ & Male $53 \%$ & \\
\hline & Black 1.9\% & & & \\
\hline & Asian 1.6\% & & & \\
\hline
\end{tabular}

Participants

Participants in academic year one included early fall 4th grade students $(N=160)$ in seven comparison group classrooms and spring 3 rd grade students $(N=133)$ in seven treatment group classrooms across two elementary schools in the same Northeastern U.S. county. In their own Grade 3 year, the 4th grade comparison group students had the same set of teachers and were exposed to the same state mandated mathematics curriculum as the $3^{\text {rd }}$ grade students who received the treatment in this study. Participants in academic year two included seven classrooms of early fall $4^{\text {th }}$ grade students who had experienced the study treatment in the spring of academic year one. In the fall of the second academic year of this study, 
students new to the schools $(N=13)$ took assessments, but their scores were not included in the study analysis. School principals and the author's Institutional Review Board approved and granted permissions for all assessment and treatment procedures.

\section{Procedures}

\section{Assessments}

Year one. At the beginning of their $4^{\text {th }}$ grade school year, comparison group students in seven classes across the two study schools $(N=160)$ completed a timed multiplication facts inventory to ascertain multiplication facts acquisition and retention from their $3^{\text {rd }}$ grade year. Classroom teachers administered the assessments.

Year two. Rising $4^{\text {th }}$ grade students who received the treatment intervention during Grade 3 were tested using the same facts inventory instrument used for the comparison group classrooms the previous fall. Students in year two who were new to the schools took the assessment administered by classroom teachers. However, new student scores were omitted from the study analysis given that they had not experienced the intervention in Grade 3.

\section{Treatment}

The treatment took place in Grade 3 classrooms from March through May during the spring of academic year one. Treatment consisted of ten 30-minute sessions of multiplication facts exploration activities and practice. For example, students explored first the products of square numbers 1-12. Children engaged in matching activities where partners had sets of cards with products in one pile and factor pairs in another. They worked together and then independently to arrange corresponding cards in tabular fashion at their desks or on the floor. Another day they "tested" one another using homemade fact flip books of the nines fact family after inspecting and discussing interesting nines products relationships on a 10x10 products grid commonly found in elementary classrooms.

The fact families were addressed in non-linear fashion, with facts in the sevens and eights families explored before the fours and sixes. This non-linear process was adopted to address participants' problematic recall of sevens facts, in particular, as well as eights facts due to possible discrimination difficulties for even numbered products in the fact families of both four and six. For products in the sevens family of facts, participants were asked to work with just two sequential facts during any study time-for example, $7 \times 6$ and $7 \times 7$ to help learners gain confidence. After most products were automatized for recall, the family of products was fitted together as a complete set 1-12.

The researcher conducted all treatment sessions, systematically replicating activities and materials in each of the seven classrooms. Intervention sessions took place with one-week intervals. A week was missed on two occasions at each school to accommodate school-based state standardized testing and district spring vacations.

\section{Data collection instruments}

The multiplication facts inventory included a paper and pencil test of forty-eight facts representing $1 \times 1$ through $9 \times 9$ (plus $0 \times 5,0 \times 6$ and $0 \times 7$ ) with no reverse facts. For example, $7 \times 9$ was presented, but not $9 \times 7$. Even though students had worked with all facts during the intervention, regardless of operand order, this inventory design was utilized as a possible way to capture internalization of more facts due to lower leading operands in the facts presentation (see Steel \& Funnell, 2001; Zhou et al., 2007). Consideration of student motivation and test-taking stress was also a factor in minimizing the number of inventory items.

Students were given up to two minutes to complete the inventory administered by their classroom teachers. Teachers read instructions from a script that asked students to complete the assessment as quickly as possible, checking first for familiar facts on the page. They were also asked to quietly turn over their paper as soon as they were done. Since the goal was to examine automaticity for presented facts, this prompt served to dissuade children from reviewing their answers before signaling completion.

Some students needed more time than others depending upon actual facts retention and/or the ability to properly record handwritten numerical answers. Even so, no participant had more than two minutes to attempt completion. At the beginning of the following year, $4^{\text {th }}$ grade students who had experienced the intervention during the spring of their Grade 3 year in these same two schools were tested using the same multiplication facts inventory instrument. As in the previous year, classroom teachers administered the assessments.

\section{Results}

Research question \#1: Working with the data

Table 2. Shows Descriptive Statistics for Measures Used In The Present Study

\begin{tabular}{|c|c|c|c|c|c|}
\hline & Treatment & $N$ & Mean & $\begin{array}{c}\text { Std. } \\
\text { Deviation }\end{array}$ & $\begin{array}{l}\text { Std. } \\
\text { Error of } \\
\text { Mean }\end{array}$ \\
\hline \multirow{2}{*}{$\begin{array}{c}\text { Attempted } \\
\text { Correct }\end{array}$} & $\begin{array}{c}\text { No } \\
\text { Treatment }\end{array}$ & 160 & .90482 & 118077 & .009335 \\
\hline & Treatment & 133 & .95372 & .062699 & .005437 \\
\hline \multirow{2}{*}{$\begin{array}{c}\text { Possible } \\
\text { Correct }\end{array}$} & $\begin{array}{c}\text { No } \\
\text { Treatment }\end{array}$ & 160 & .46868 & .235569 & .01623 \\
\hline & Treatment & 133 & 66349 & .219112 & 018999 \\
\hline
\end{tabular}

Independent-samples t-tests were conducted to compare "attempted correct" and "correct out of possible" scores between the no treatment and treatment conditions. There was a significant difference in the "attempted correct" scores for no treatment $(M=.90, S D=.12)$ and treatment $(M=.95, S D=.06) ; t_{(250)}=4.53, p<.001, d=0.52$. Additionally, there was a significant difference in the "correct out of all possible" scores for no treatment $(M=.47, S D=$ $.24)$ and treatment $(M=.66, S D=.22) ; t(291)=7.274, p<.001$, $d=0.86$.

These results suggest that having $3^{\text {rd }}$ grade students experience facts learning support for multiple short exploratory sessions during the spring did have an effect on facts retention into the $4^{\text {th }}$ grade year. Relative to research question \#1, student scores for both attempted correct and scores for correct out of all possible facts improved. Specifically, when students experienced supplementary activities that support learning facts in Grade 3, their memory retention for multiplication facts increased.

Pearson product moment correlations were computed for the treatment group and both "attempted correct" and "correct out of possible" test scores. Results shown in table 1.3 suggest that correlations between treatment and scores in both situations were statistically significant and were greater than or equal to $r_{(291)}=.244, p<.01$ and $r_{(291)}=$ $.392, p<.01$. 
Table 3. Correlations

\begin{tabular}{|c|c|c|c|c|}
\hline & & $\begin{array}{c}\text { Attempted } \\
\text { Correct }\end{array}$ & Possible Correct & Treatment \\
\hline \multirow{3}{*}{$\begin{array}{l}\text { Attempt } \\
\text { Correct } \\
\text { Correlation }\end{array}$} & Pearson & 1 & $.499 * *$ & $.244^{\star *}$ \\
\hline & Sig. (2-tailed) & & .000 & .000 \\
\hline & $N$ & 293 & 293 & 293 \\
\hline \multirow{3}{*}{$\begin{array}{c}\text { Possible } \\
\text { Correct } \\
\text { Correlation }\end{array}$} & Pearson & $.499 * *$ & 1 & $.392^{\star *}$ \\
\hline & Sig. (2-tailed) & .000 & & .000 \\
\hline & $N$ & 293 & 293 & 293 \\
\hline \multirow{3}{*}{$\begin{array}{l}\text { Treatment } \\
\text { Correlation }\end{array}$} & Pearson & $.244^{* *}$ & $.392^{* *}$ & 1 \\
\hline & Sig. (2-tailed) & .000 & .000 & \\
\hline & $N$ & 293 & 293 & 293 \\
\hline
\end{tabular}

\section{Research question \#2}

A second aim of this pilot study was to examine feasibility for the ten-week intervention. As mentioned previously, the timeframe for the study intervention was actually twelve weeks in both schools due to two missed weeks, one for mandatory state educational testing and another for the scheduled spring vacation. Principals and teachers agreed upon feasibility benchmarks before the study commenced. Criteria included:

1) Timing - 30 minutes sessions preceded or followed regular mathematics instruction periods in each classroom, whichever best suited individual teacher plans

2) Instructional materials - these were designed to be easily procured or replicated for teachers future use

3) Student engagement - moderate to high levels were to be maintained for the duration of the intervention

4) Classroom teachers' role - teachers served as instructional assistants, but were not responsible for intervention planning or activity presentations

\section{Working with the data}

Teachers in each school met first with their principal before gathering with the researcher to debrief following the study intervention. Quantitative results had not been analyzed at the time of the reflection, so it was not yet known whether gains had occurred from one year to the next. Teachers offered anecdotal evidence of student facts acquisition gains when they believed these to be present. However, these comments did not influence quantitative analysis of the data involving assessments completed by comparison and treatment groups. Teachers also provided feedback regarding student engagement during the intervention and whether they felt it was important or possible to set aside dedicated time blocks for the purpose of student multiplication facts acquisition. Reflection elements and feedback on the intervention process were meant to provide a framework for a future, more balanced mixed-methods study.

Table 4 displays data from reflection sessions. Stakeholder feedback is set out in separate columns for each reflection topic.

Teachers and principals agreed that implementing focused multiplication facts instruction in novel ways was desirable and ultimately feasible during the late winter and into spring of the Grade 3 academic year. Teachers felt that student confidence with facts increased over the treatment weeks compared to their students in other years. This anecdotal evidence was important to them in their professional practice, but it did not specifically sup- port research questions for this study.

\section{Discussion}

Treatment group students received a total of five hours of supplemental instruction for facts memorization. Results suggest that these students had better facts retention at the beginning of their Grade 4 year, as compared to school peers who experienced the same mathematics curriculum and set of teachers the previous year. Importantly, improvement was evident even though all students experienced some facts memorization activities embedded in programmatic mathematics instruction both years.

The Pearson correlation between treatment and both "attempted correct" and "possible correct" on the facts inventory was in both cases statistically significant $(p<.001)$ with a Pearson correlation value for possible correct approaching medium range at .392. An important finding is that the correlation between attempted correct and correct solutions out of all possible facts (.499) sits on the precipice of fitting into the medium range generally accepted for correlations (.500). These results suggest that treatment group students attempted to complete more items on the facts assessment inventory and, in the process, provided more correct solutions than comparison group students.

Treatment students may have attempted to answer more items than their comparison group peers because they had confidence in their ability to answer additional items correctly. While this element is beyond the scope of the current study, a follow-up study may seek to gather data about student mathematics self-concept related to multiplication facts interventions. It would be important to understand, among other things, how students feel about their level of automaticity with multiplication facts, the facts acquisition assessment process, and what types of assistance are personally meaningful during the memorization process.

In terms feasibility of a dedicated focus on facts acquisition for automaticity, teachers felt that with professional development they would be able to institute such an approach without compromising an already full teaching schedule designed to meet curricular requirements at the school, district, and state levels. If five hours spread over a number of weeks could make a difference, they would find the time to work with their students toward facts automaticity. Principals concurred.

\section{Study Limitations and Future Research}

While the same set of teachers at each of the study schools taught both student groups during the $3^{\text {rd }}$ and $4^{\text {th }}$ 
Table 4.

\begin{tabular}{|c|c|c|c|}
\hline & \multicolumn{3}{|c|}{ Stakeholders } \\
\hline $\begin{array}{l}\text { Benefit of dedicated } \\
\text { time block for facts }\end{array}$ & $\begin{array}{l}\text { Agreement that students ben- } \\
\text { efitted from a dedicated facts } \\
\text { acquisition time block }\end{array}$ & $\begin{array}{l}\text { Wanted to see data be- } \\
\text { fore making a decision }\end{array}$ & $\begin{array}{c}\text { Observed student facts acquisition gains, } \\
\text { but did not know whether gains would } \\
\text { be statistically different from year one } 4^{\text {th }} \\
\text { graders when } 3^{\text {rd }} \text { graders rose to Grade } \\
4 \text { in the fall }\end{array}$ \\
\hline $\begin{array}{l}\text { Timing } \neg- \\
\text { 30-minutes }\end{array}$ & $\begin{array}{c}\text { Agreement that } 30 \text {-minutes } \\
\text { was suitable for student focus } \\
\text { and flexibility within the weekly } \\
\text { school schedule. Agreement } \\
\text { that } 30 \text { minutes was often not } \\
\text { long enough given high student } \\
\text { engagement. }\end{array}$ & $\begin{array}{l}\text { Agreement that time for } \\
\text { facts every week, for ten } \\
\text { weeks was acceptable as } \\
\text { long as literacy did not } \\
\text { experience a reduced } \\
\text { focus }\end{array}$ & $\begin{array}{l}\text { Thirty minutes was not long enough } \\
\text { for particular sessions, given student } \\
\text { engagement. The time block was likely } \\
\text { suitable, however, for continuing the } \\
\text { process if gains were actualized. }\end{array}$ \\
\hline $\begin{array}{l}\text { Timing - } \\
\text { academic year }\end{array}$ & $\begin{array}{l}\text { Two teachers felt the Mar-May } \\
\text { timing was correct. Five teachers } \\
\text { felt the sessions could be sched- } \\
\text { uled late Jan-Mar. }\end{array}$ & $\begin{array}{c}\text { Principals deferred } \\
\text { to teachers regarding } \\
\text { timing for their particular } \\
\text { classes. }\end{array}$ & $\begin{array}{l}\text { Conceptual understanding of multiplica- } \\
\text { tion as repeated addition of like number } \\
\text { groups is recommended before asking } \\
\text { students to memorize facts. Explorations } \\
\text { for conceptual understanding were } \\
\text { well underway in Grade } 2 \text { and Grade } \\
3 \text { classrooms before the interventions } \\
\text { commenced. }\end{array}$ \\
\hline Teaching load & $\begin{array}{l}\text { Agreement that if facts acqui- } \\
\text { sition gains were measureable, } \\
\text { teaching load would not be } \\
\text { affected. Student learning could } \\
\text { be more streamlined overall. } \\
\text { Dedicated sessions could be } \\
\text { repeated every year, with little } \\
\text { extra planning. }\end{array}$ & $\begin{array}{l}\text { Agreement that teachers } \\
\text { could not experience } \\
\text { increased teaching load } \\
\text { without various approv- } \\
\text { als. Teachers would have } \\
\text { to recognize gains and } \\
\text { plan accordingly, fitting } \\
\text { dedicated facts sessions } \\
\text { into weekly teaching plan. }\end{array}$ & \\
\hline
\end{tabular}

Grade years, there are other variables that may have affected facts acquisition from one year to the next beyond the study treatment. Teacher attitudes about mathematics in general and the value of facts automaticity; attention to individual learning needs; and memorization expectations both in school and at home, are just a few. Additionally, teachers would need professional development to become more attuned to efficient, flexible, exploratory instructional methods for facts acquisition with their students.

Teacher attitudes, mathematics pedagogical content knowledge, and pedagogical styles may be taken up in a qualitative element of a larger study. In addition, a follow-up study would seek to control for additional elements regarding information that can be garnered for each individual student in comparison and treatment groups.

\section{Conclusion}

Educators want students to achieve their full potential in mathematics. If it is known that multiplication facts automaticity matters in the long-term for both student self-concept and success with mathematics at higher levels, teachers, families, and school administrators must find ways to systematically support the automatization process. Research on facts acquisition methods and ma- terials is important to consider in light of there being so little available upon which teachers might draw in order to ameliorate weak facts automaticity in their students. Methods used for decades do not seem to help enough students, and now busy families may be less available or able to encourage or assist children with facts practice in the home. Rather than rely on a concept-based only approach to multiplication facts in schools in the face of difficulty helping children to attain automaticity, we must seek to successfully combine concept development with real automaticity for optimum student achievement.

\section{References}

Atweh, B., \& Clarkson, P. (2001). Internationalization and globalization of mathematics education: Toward an agenda for research/action. In B. Atweh, H. Forgasz, \& B. Nebres (Eds.), Sociocultural research on mathematics education (pp. 77-94). Mahwah, NJ: Lawrence Erlbaum Associates.

Boyer, C. B. (1991). A history of mathematics (2nd ed.). New York: John Wiley \& Sons.

Burns, M. K., Ysseldyke, J., Nelson, P. M., \& Kanive, R. (2015). Number of repetitions required to retain single-digit multiplication math facts for elemen- 
tary students. School Psychology Quarterly, 30(3), 398-405. doi:10.1037/spq0000097

Chapin, S. H., \& Johnson, A. (2006). Math matters (2nd ed.). Sausalito, CA: Math Solutions Publications.

Codding, R. S., Burns, M. K., \& Lukito, G. (2011). Meta-analysis of mathematic basic-fact fluency interventions: A component analysis. Learning Disabilities Research \& Practice, 26(1), 36-47. doi:10.1111/ j.1540-5826.2010.00323.x

D'Ambrosio, U., \& D'Ambrosio, B. (1994). An international perspective on research through the JRME. Journal for Research in Mathematics Education, 25(6), 685 696. http://dx.doi.org/10.2307/749580

Dehaene, S. (1997). The number sense: How the mind creates mathematics. Oxford: Oxford University Press.

Geary, D. C. (1994). Children's mathematical development. Washington, DC: American Psychological Association.

Geary, D. C. (1999). Sex differences in mathematical abilities: Commentary on the math-fact retrieval hypothesis. Contemporary Educational Psychology, 24(3), 267-274. http://dx.doi.org/10.1006/ ceps.1999.1007

Geary, D. C., Saults, S. J., Liu, F., \& Hoard, M. K. (2000). Sex differences in spatial cognition, computational fluency, and arithmetical reasoning. Journal of Experimental Child Psychology, 77(4), 337-353. doi:10.1006/jecp.2000.2594

Goswami, U. (2008). Principles of learning, implications for teaching: A cognitive neuroscience perspective. Journal of Philosophy of Education, 42(3/4), 381399. doi:10.1111/j.1467-9752.2008.00639.x

Hamann, M. S., \& Ashcraft, M. H. (1986). Textbook presentations of the basic addition facts. Cognition and Instruction, 3(3), 173-202. doi:10.1207/s1532690xci0303_2

LeFevre, J.-A., DeStefano, D., Coleman, B., \& Shanahan, T. (2005). Mathematical cognition and working memory. In J. I. D. Campbell (Ed.), Handbook of mathematical cognition (pp. 361-377). New York: Psychology Press.

Mahler, J. D. (2011). When multiplication facts won't stick: Could a language/story approach work? A research study examining the effectiveness of the "memorize in minutes" curriculum. The Educational Therapist, 32(1), 5-8, 20-21. Retrieved from: http://www.eric.ed.gov/contentdelivery/servlet/ ERICServlet?accno= ED527570

Marsh, H. W. \& Hau, K.-T. (2004). Explaining paradoxical relations between academic self-concepts and achievements: Cross-cultural generalizability of the internal/external frame of reference predictions across 26 countries. Journal of Education al Psychology, 96(1), 56-67. doi:10.1037/00220663.96.1.56

National Research Council. (2005). Adding it up: Helping children learn mathematics. Washington, DC: National Academy Press.
National Mathematics Advisory Panel. (2008). Foundations for success: The final report of the National Mathematics Advisory Panel. Retrieved from https:// www2.ed.gov/about/bdscomm/list/mathpanel/report/final-report.pdf

Qin, S., Cho, S., Chen, T., Rosenberg-Lee, M., Geary, D. C., \& Menon, V. (2014). Hippocampal-neocortical functional reorganization underlies children's cognitive development. Nature Neuroscience, 17(9), 12631269. doi:10.1038/nn.3788

Royer, J. M. (Ed.). (2003). Mathematical cognition. Greenwich, CT: Information Age.

Siegler, R. S. (1988). Strategy choice procedures and the development of multiplication skill. Journal of Experimental Psychology: General, 117(3), 258-275. doi:10.1037/0096-3445.117.3.258

Smith, D. E. (1958). History of mathematics (Vol. 1). Toronto, Canada: General Publishing Company.

Steel, S., \& Funnell, E. (2001). Learning multiplication facts: A study of children taught by discovery methods in England. Journal of Experimental Child Psychology, 79(1), 37-55. doi:http://dx.doi.org/10.1006/ jecp. 2000.2579

Thomas, J. (2001). Globalization and the politics of mathematics education. In B. Atweh, H. Forgasz, \& B. Nebres (Eds.), Sociocultural research on mathematics education (pp. 95-112). Mahwah, NJ: Lawrence ErIbaum.

Valero, P. (2004). Postmodernism as an attitude of critique to dominant mathematics education research. In M. Walshaw (Ed.), Mathematics education within the postmodern. Greenwich, CT: Information Age.

Williams, T., \& Williams, K. (2010). Self-efficacy and performance in mathematics: Reciprocal determinism in 33 nations. Journal of Educational Psychology, 102(2), 453-466. doi:10.1037/a0017271

Zhou, X., Chen, C., Zhang, H., Chen, C., Zhou, R., \& Dong, Q. (2007). The operand-order effect in single-digit multiplication: An ERP study of Chinese adults. Neuroscience Letters, 414(1), 41-44. doi:10.1016/j. neulet.2006.06.078 